\title{
Ramipril and aminoguanidine restore renal lysosomal processing in streptozotocin diabetic rats
}

\author{
T.M. Osicka ${ }^{1}$, Z. Kiriazis ${ }^{2}$, L. M.Pratt ${ }^{2}$, G.Jerums ${ }^{1}$, W. D. Comper ${ }^{2}$ \\ ${ }^{1}$ Endocrine Unit, Department of Medicine, University of Melbourne, Austin \& Repatriation Medical Centre, Heidelberg, \\ Victoria, Australia \\ ${ }^{2}$ Department of Biochemistry and Molecular Biology, Monash University, Clayton, Victoria, Australia
}

\section{Abstract}

Aims/hypothesis. We aimed to examine the time course for the diabetes-related changes in renal lysosomal processing and to determine whether these changes can be prevented by aminoguanidine or ramipril treatment.

Methods. The percentage desulphation of intravenously injected tritium labelled dextran sulphate $\left(\left[{ }^{3} \mathrm{H}\right] \mathrm{DSO}_{4}\right)$ in the urine, as determined by ion-exchange chromatography, was used as a marker of lysosomal sulphatase activity. Sulphatase activity was determined 1,2, 3 and 4 weeks after the onset of diabetes in rats as well as in rats treated with either aminoguanidine or ramipril for twelve weeks.

Results. The amount of totally desulphated $\left[{ }^{3} \mathrm{H}\right] \mathrm{DSO}_{4}$ in urine collected from control rats was $65.6 \pm 0.8 \%$. This was significantly reduced in diabetic rats two $(57.4 \pm 1.4 \%$ desulphated), three $(56.8 \pm 1.3 \%$ desulphated $)$ and four $(52.9 \pm 2.2 \%$ desulphated) weeks after the onset of diabetes. The significant decrease in the amount of totally desulphated $\left[{ }^{3} \mathrm{H}\right] \mathrm{DSO}_{4}$ in the urine also found at 12 weeks after the onset of diabetes was not affected by drug treatment. There was no significant difference in the amount of partially desulphated $\left[{ }^{3} \mathrm{H}\right] \mathrm{DSO}_{4}$ in the urine between all the study groups. However, the increase in totally sulphated $\left.{ }^{3}{ }^{3} \mathrm{H}\right] \mathrm{DSO}_{4}$ in the urine collected from diabetic rats $(8.7 \pm 1.7 \%$ sulphated) compared with that of control rats $(2.2 \pm 0.5 \%$ sulphated) was normalised by treatment with both aminoguanidine $(4.8 \pm 1.6 \%$ sulphated $)$ or ramipril $(4.5 \pm 0.8 \%$ sulphated $)$.

Conclusions/interpretation.These results raise the possibility that the diabetes-induced changes in renal lysosomal processing may be one of the initial events in the development of diabetic nephropathy. Aminoguanidine and ramipril, known for their different mechanism of action, seem to prevent diabetes-induced changes in lysosomal processing either through their effects on enzyme activity within the lysosome or through their effects on the trafficking of molecules to and from the lysosome. [Diabetologia (2001) 44: 230-236]

Keywords Lysosomes, dextran sulphate, sulphatase, albumin fragmentation, protein kinase $\mathrm{C}$.
Received: 26 June 2000 and in revised form: 9 October 2000

Corresponding author: Dr Wayne D. Comper, Department of Biochemistry and Molecular Biology, Monash University, Clayton, Victoria, Australia, 3800

Abbreviations: AG, aminoguanidine; RAM, ramipril; STZ, streptozotocin; $\mathrm{DSO}_{4}$, dextran sulphate; GCW, glomerular capillary wall; $\mathrm{GHb}$, glycated haemoglobin; $\left[{ }^{3} \mathrm{H}\right] \mathrm{DSO}_{4}$, tritium labelled dextram sulphate; PKC, protein kinase C; DAG, diacylglycerol; w/v, weight-to-volume.
Our recent studies on rats [1-6] and on human beings [7] using tritium labelled albumin $\left(\left[{ }^{3} \mathrm{H}\right]\right.$ albumin $)$ have shown that albumin, after being filtered, is fragmented into small peptides $(<15 \mathrm{kD})$. This is an extremely rapid and efficient process, which occurs within minutes and involves lysosomal uptake and regurgitation of peptide products back to the tubular lumen. In healthy rats and humans, the albumin-derived fragments represent more than $90 \%$ of urinary albumin compared with less than $10 \%$ of intact albumin. We also observed that the percentage ratio between in- 
tact and fragmented albumin is reversed in both experimental diabetes $[5,6]$ and in subjects with Type I (insulin-dependent) diabetes mellitus [7]. Aminoguanidine and ramipril have been shown to normalise the fragmentation process in streptozotocin (STZ)-diabetic rats [6]. The exact anatomical location of this "degradation pathway" has not been found but it is most likely to occur by endocytosis and lysosomal degradation in proximal tubule cells. Histochemical and electron microscopical studies [8] have shown that, following endocytosis, larger molecular weight proteins are degraded within the lysosomes of the epithelial cells in proximal convoluted tubules. ${ }^{125}$ I-labelled bovine serum albumin has also been shown to be degraded by lysates of rat kidney lysosomes [9]. The degradation pathway seems to be non-specific since all proteins tested to date have been shown to be degraded, including horseradish peroxidase, immunoglobulin $G$ and albumin [1-7], the extent of degradation varying from protein to protein. The pathway will affect the concentration of protein excretion measured as existing immunochemical assays do not detect fragments but only intact material $[2,5,7]$.

Alterations in lysosomal enzyme activity, which have been reported to be reduced in short-term (up to three weeks) diabetic rats, could affect the degradation pathway. For example, renal proteolytic activity was reduced by about $25 \%$ in isolated glomeruli [10] and proximal tubules [11], and lower activities $(\sim 20-25 \%)$ of lysosomal enzymes such as cathepsins $\mathrm{L}, \mathrm{B}$ and $\mathrm{D}[12,13]$ have been reported. We have also shown that the decreased cathepsin activity continues after 24 weeks of diabetes [6]. Although lysosomal enzyme activity has been measured in ex situ or in vitro preparations, no direct estimation of lysosomal activity in vivo has been made.

Recently, a direct method of estimating lysosomal processing in vivo has been developed, which estimates lysosomal sulphatase activity by measuring the degree of desulphation of tritium labelled dextran sulphate $\left(\left[{ }^{3} \mathrm{H}\right] \mathrm{DSO}_{4}\right)$ during renal passage $[14,15]$. Sulphatase, a specific lysosomal hydrolase, has been shown to have considerable biochemical activity in glomerular cells of the rat $[16,17]$. Studies on the glomerular processing of $\left[{ }^{3} \mathrm{H}\right] \mathrm{DSO}_{4}$ in STZ-diabetic rats have shown that glomerular sulphatase activity is reduced after 4 weeks of diabetes, so that $\left[{ }^{3} \mathrm{H}\right] \mathrm{DSO}_{4}$ appearing in the urine is not desulphated [15]. This contrasts with extensive desulphation of the $\left[{ }^{3} \mathrm{H}\right] \mathrm{DSO}_{4}$ molecule in the urine collected from control rats [15]. The decrease in desulphation is likely to be a direct consequence of the decrease in sulphatase activity in vivo which has been shown to be linked with vesicles that are transported to lysosomes [18].

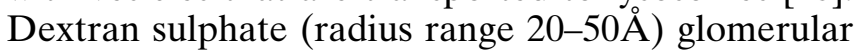
capillary wall (GCW) permeability will not be significantly altered in STZ-diabetic rats as its glomerular sieving is identical to dextran at sufficiently high con- centration and dextran (radius range $20-50 \AA$ ) fractional clearance is not altered in diabetic nephropathy [19-21]. Therefore, the reduction in sulphatase activity is likely to reflect a decreased activity of enzymes or altered intracellular processing associated with lysosomal degradation in diabetes [6,10-13]. For example, the activity of cathepsin and metalloprotease in glomeruli has been shown to decrease after only 4 days of diabetes and to continue to decrease 5 weeks after the onset of diabetes in insulin untreated rats [22]. The decreased lysosomal enzyme activity observed in the STZ-diabetic rat is consistent with the decrease in albumin fragmentation observed as early as 4 weeks after the onset of diabetes [5]. Therefore, the desulphation of $\left[{ }^{3} \mathrm{H}\right] \mathrm{DSO}_{4}$ could be used as a direct in vivo marker of lysosomal enzyme activity. Because sulphatase is specifically located in lysosomes, other proteolytic events which are not lysosomal do not contribute to the changes observed in diabetes.

In this study we determined the in vivo degree of desulphation of $\left[{ }^{3} \mathrm{H}\right] \mathrm{DSO}_{4}$ in urine collected from control rats and STZ-diabetic rats injected intravenously with $\left[{ }^{3} \mathrm{H}\right] \mathrm{DSO}_{4} 1,2,3,4$ and 12 weeks after the onset of diabetes using ion-exchange chromatography. The effects of angiotensin converting enzyme (ACE) inhibition with ramipril and the anti-glycation agent aminoguanidine on the degree of desulphation are also examined in control and STZ-diabetic rats after 12 weeks of treatment.

\section{Materials and methods}

STZ-diabetic rat model. Fasting male Sprague Dawley rats (Animal Resource Centre, Perth, Australia, Heidelberg, Australia), aged between 6 and 7 weeks and weighing between 200 and $250 \mathrm{~g}$, were chosen at random to receive an intravenous injection of STZ (Sigma Chemical, St. Louis, Mont., USA) at a dose of $50 \mathrm{mg} / \mathrm{kg}$ or sodium citrate buffer $(\mathrm{pH} 4.5$ for control rats only). Only diabetic animals with blood glucose of greater than $15 \mathrm{mmol} / \mathrm{l}$ were included in the study. Diabetic animals were given either $4 \mathrm{U}$ of long-acting insulin (Ultralente, Novo Nordisk, Bagsvaerd, Denmark) three times a week (for the 1,2, 3 and 4 week time points) or $2 \mathrm{U}$ of long-acting insulin daily (for the 12 week time point) to maintain body weight and to prevent ketoacidosis. All animals had free access to rat food and water.

For the 12 week study, diabetic and control animals were randomised to receive one of the following three drug regimens: (1) no treatment, (2) aminoguanidine (Fluka Chemica, Buchs, Switzerland) at a dose of $1 \mathrm{~g} / \mathrm{l}$ for diabetic rats and $3 \mathrm{~g} / \mathrm{l}$ for control rats in drinking water; (3) ramipril (Hoechst, Frankfurt, Germany) at a dose in drinking water of $3 \mathrm{mg} / \mathrm{l}$ for diabetic rats and $9 \mathrm{mg} / \mathrm{l}$ for control rats for 12 weeks. These doses were chosen because they ameliorate albuminuria [23-25].

The following parameters were measured every 4 weeks throughout the study: body weight, blood glucose by glucometer (Accutrend, Boehringer Mannheim GmbH Biochemica, Mannheim, Germany), systolic blood pressure (BP) measured by tail-cuff plethysmography in conscious, warmed rats [26], glycohaemoglobin (GHb) by high-performance liquid chroma- 
Table 1. Biochemical parameters and animal characteristics for 12 week control and diabetic rats treated with aminoguanidine or ramipril

\begin{tabular}{|c|c|c|c|c|c|c|c|c|c|}
\hline & $n$ & $\begin{array}{l}\text { Glucose } \\
(\mathrm{mmol} / \mathrm{l})\end{array}$ & $\begin{array}{l}\mathrm{GHb} \\
(\%)\end{array}$ & $\begin{array}{l}\text { Body weight } \\
\text { (g) }\end{array}$ & $\begin{array}{l}\text { Kidney weight: } \\
\text { Body weight } \\
\left(\times 10^{-3}\right)\end{array}$ & $\begin{array}{l}\text { GFR } \\
(\mathrm{ml} / \mathrm{min})\end{array}$ & $\begin{array}{l}\text { Urine } \\
\text { volume } \\
(\mathrm{ml} / 24 \mathrm{~h})\end{array}$ & $\begin{array}{l}\mathrm{BP} \\
(\mathrm{mmHg})\end{array}$ & $\begin{array}{l}\text { AER } \\
(\mathrm{mg} / 24 \mathrm{~h})\end{array}$ \\
\hline $\mathrm{C}$ & 6 & $5.4 \pm 0.2$ & $3.6 \pm 0.2$ & $453 \pm 8$ & $6.36 \pm 0.26$ & $3.17 \pm 0.20$ & $15 \pm 1$ & $133 \pm 3$ & $0.46 \times / \div 1.17$ \\
\hline $\mathrm{C}+\mathrm{RAM}$ & 6 & $5.8 \pm 0.2$ & $3.3 \pm 0.6$ & $402 \pm 17$ & $7.12 \pm 0.23$ & $3.32 \pm 0.18$ & $22 \pm 2$ & $130 \pm 7$ & $0.45 \times / \div 1.23$ \\
\hline D & 8 & $22.1 \pm 1.7^{\mathrm{a}}$ & $10.6 \pm 0.4^{\mathrm{a}}$ & $302 \pm 15^{\mathrm{a}}$ & $10.72 \pm 0.36^{\mathrm{a}}$ & $3.93 \pm 0.24^{\mathrm{b}}$ & $121 \pm 12^{\mathrm{a}}$ & $147 \pm 3$ & $1.04 \times / \div 1.24^{b}$ \\
\hline $\mathrm{D}+\mathrm{AG}$ & 11 & $21.4 \pm 1.5^{\mathrm{a}}$ & $9.7 \pm 0.5^{\mathrm{a}}$ & $341 \pm 22^{\mathrm{a}}$ & $10.68 \pm 0.01^{\mathrm{a}}$ & $4.13 \pm 0.17^{a}$ & $107 \pm 16^{\mathrm{a}}$ & $144 \pm 5$ & $0.93 \times 1 \div 1.32^{b}$ \\
\hline
\end{tabular}

tography (CLC330 GHb Analyzer, Primus, Kansas City, Mont., USA) [27] and glomerular filtration rate (GFR) by a single-injection isotopic technique using ${ }^{99 \mathrm{~m}}$ Tc-DTPA developed in our laboratory [28]. In addition, urine was collected from animals placed in individual metabolic cages for $24 \mathrm{~h}$ to measure the albumin excretion rate (AER) by an in-house RIA as described previously [29]. The interassay coefficient of variation was $7 \%$ at a concentration of $180 \mathrm{ng} / \mathrm{ml}$ and the detection limit of the assay was $31.2 \mathrm{ng} / \mathrm{ml}$.

Tritium labelling of dextran sulphate. $\mathrm{DSO}_{4}$ was labelled with tritium (molecular weight, 48 000) according to a method described previously [30]. This involved a brief exposure to sodium boro- $\left[{ }^{3} \mathrm{H}\right]$ hydride (Du Pont, Wilmington, Detroit, USA) followed by extensive dialysis for 3 days against distilled water and then for a further 2 days against phosphate buffered saline (PBS; $136.9 \mathrm{mmol} / \mathrm{l} \mathrm{NaCl}, 2.68 \mathrm{mmol} / \mathrm{l} \mathrm{KCl}, 8.1 \mathrm{mmol} / \mathrm{l} \mathrm{Na}{ }_{2} \mathrm{H}-$ $\mathrm{PO}_{4}, 1.5 \mathrm{mmol} / \mathrm{K} \mathrm{KH}_{2} \mathrm{PO}_{4}, \mathrm{pH} 7.4$ ). The dialysed preparation was applied to a PD-10 column immediately before being used to remove any free tritium. The specific activity of the sample was determined to be $9.48 \cdot 10^{6} \mathrm{dpm} / \mathrm{mg}$ by measuring the hexose content [31].

Processing of dextran sulphate in vivo. Control and diabetic rats at 1, 2, 3, 4 and 12 weeks after the onset of diabetes, were intravenously injected with $2.0 \mathrm{mg}\left[{ }^{3} \mathrm{H}\right] \mathrm{DSO}_{4}$ which corresponds to $1.91 \cdot 10^{7} \mathrm{dpm}$, in the tail vein and maintained in a metabolic cage for $3 \mathrm{~h}$ with free access to food and water. The urine collected during this period was analysed by ion-exchange using a Q-Sepharose (Pharmacia Fine Chemicals, Uppsala, Sweden) column. The samples were buffered with $6 \mathrm{~mol} / \mathrm{l}$ Urea, $0.05 \mathrm{~mol} / 1$ Tris, $0.05 \%$ (w/v) CHAPS, at $\mathrm{pH} \mathrm{7.0,} \mathrm{and}$ eluted with a linear gradient of $0.15-2.5 \mathrm{~mol} / \mathrm{l} \mathrm{NaCl}$, in the same buffer at $30 \mathrm{ml} / \mathrm{h}$ collecting a total of 80 fractions of $3 \mathrm{ml}$. Fraction densities were measured in a PAAR DMA55 densitometer (Graz, Austria) at $21^{\circ} \mathrm{C}$. Column recoveries were between $95-105 \%$.

Counting of radioactivity. Radioactivity of tritium labelled material was measured by scintillation counting in a Wallac 1409 liquid scintillation analyser (Wallac, Finland), using a 1:4 aqueous sample to Optiphase scintillant ratio.

Statistics. Data are expressed as mean \pm standard error where $n$ represents the number of determinations. The albumin excretion rate is expressed as geometric mean $\times 1 \div$ tolerance factor. Normally, distributed variables in different groups were compared by analysing of variance, using the Statview program (Brain Power, Calabasas, Calif., USA). Comparisons be- tween group means were carried out by Fisher's least significant difference method. A $p$ value of less than 0.05 was considered statistically significant.

\section{Results}

Characterisation of the STZ-diabetic rat model. Only the data for the 12 week study are shown (Table 1) but similar results were obtained for the control rats and STZ-diabetic rats 1, 2, 3 and 4 weeks after the onset of diabetes. Rats had noticeably higher glucose and $\mathrm{GHb}$ concentration after 12 weeks of diabetes when compared with control rats. Aminoguanidine or ramipril therapy did not influence glycaemic control in diabetic rats. Control rats treated with aminoguanidine or ramipril had similar glucose and $\mathrm{GHb}$ levels to untreated control rats (Table 1). Systolic BP was significantly reduced in diabetic rats receiving ramipril (Table 1). Systolic BP was not affected by aminoguanidine treatment. Body weight was significantly lower in diabetic than in control rats (Table 1). At the conclusion of the study, the kidney weight-tobody weight ratio was increased in diabetic rats compared with control rats (Table 1). Aminoguanidine or ramipril therapy did not influence the kidney weight-to-body weight ratio in diabetic rats. Diabetes was associated with an increase in GFR when compared with control rats and was also only normalised by treatment with ramipril and not aminoguanidine. Control rats treated with aminoguanidine or ramipril had similar GFRs to untreated control rats (Table 1). Urine volumes as measured over a $24 \mathrm{~h}$ period were much higher in diabetic rats compared with control rats. Treatment with aminoguanidine or ramipril did not influence urine volume. Control rats treated with aminoguanidine or ramipril had similar urine volumes to untreated control rats (Table 1).

Diabetes was associated with a significantly increased AER, as measured by RIA over the 12 week study period, when compared with control rats $\mathrm{Ta}-$ ble 1). Treatment of diabetic rats with ramipril but not aminoguanidine prevented an increase in AER. 


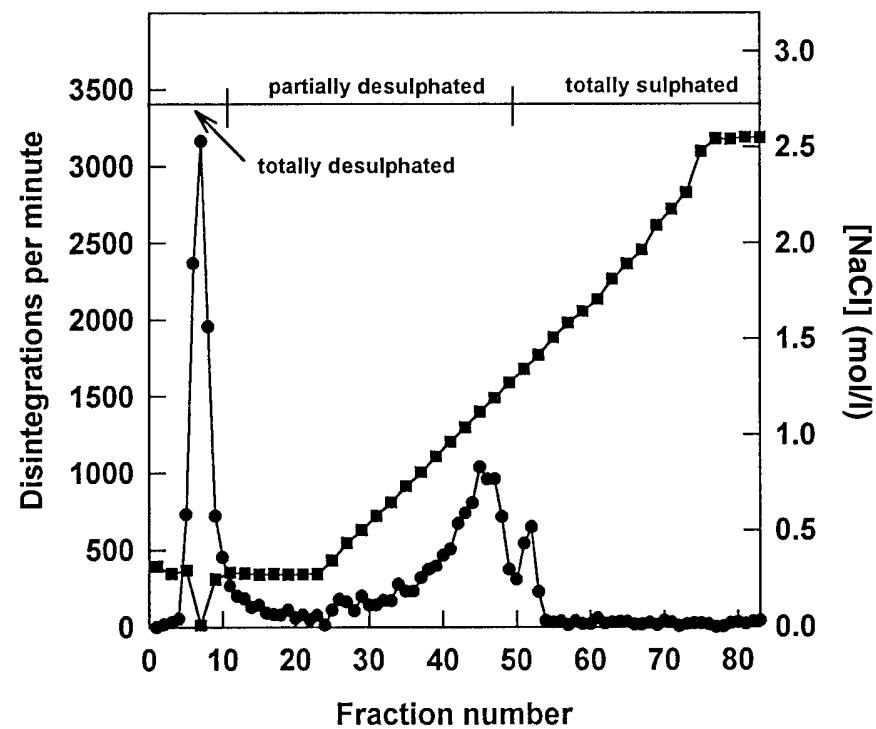

Fig. 1. Representative profile of $\left[{ }^{3} \mathrm{H}\right] \mathrm{DSO}_{4}$ in urine collected from 12 week STZ-diabetic rats following the intravenous injection of $\left[{ }^{3} \mathrm{H}\right] \mathrm{DSO}_{4}$ as analysed using ion-exchange chromatography on Q-Sepharose showing the distribution of totally desulphated, partially desulphated and totally sulphated material (O). The $\mathrm{NaCl}$ gradient is also shown (

Table 2. Analysis of sulphatase activity in urine from 12 week control and STZ-diabetic rats treated with aminoguanidine or ramipril

\begin{tabular}{lllll}
\hline & $n$ & $\begin{array}{c}\text { \% totally } \\
\text { desulphated }\end{array}$ & $\begin{array}{l}\text { \% partially } \\
\text { desulphated }\end{array}$ & $\begin{array}{l}\text { \% un- } \\
\text { desulphated }\end{array}$ \\
\hline C & 6 & $66.2 \pm 4.1$ & $31.6 \pm 3.8$ & $2.2 \pm 0.5$ \\
C + AG & 6 & $60.2 \pm 1.5$ & $37.1 \pm 0.9$ & $2.7 \pm 0.5$ \\
C + RAM & 5 & $56.6 \pm 5.4$ & $40.1 \pm 5.1$ & $3.3 \pm 1.0$ \\
D & 6 & $52.8 \pm 1.5^{\mathrm{a}}$ & $38.5 \pm 2.2$ & $8.7 \pm 1.7^{\mathrm{a}}$ \\
D + AG & 9 & $55.9 \pm 1.6$ & $39.3 \pm 1.1$ & $4.8 \pm 1.6^{\mathrm{b}}$ \\
D + RAM & 6 & $57.4 \pm 1.1$ & $38.1 \pm 0.9$ & $4.5 \pm 0.8^{\mathrm{b}}$ \\
\hline
\end{tabular}

Data are expressed as mean \pm standard error

${ }^{a} p<0.005$ vs appropriate control

${ }^{\mathrm{b}} p<0.02$ vs diabetic

Albuminuria was similar in untreated control rats and in those receiving aminoguanidine or ramipril.

Sulphatase activity in control and STZ-diabetic rat urine. Figure 1 shows a representative elution profile of $\left[{ }^{3} \mathrm{H}\right] \mathrm{DSO}_{4}$ in urine collected from 12 week STZ-diabetic rats after an intravenous injection of $\left[{ }^{3} \mathrm{H}\right] \mathrm{DSO}_{4}$ as analysed on an ion-exchange column. The profile has been divided into three distinct sections corresponding to different degrees of desulphation. The first peak (fractions 1-15) is completely desulphated $\left[{ }^{3} \mathrm{H}\right] \mathrm{DSO}_{4}$ in the urine and elutes at a $\mathrm{NaCl}$ concentration of $0.15 \mathrm{~mol} / \mathrm{l}$. The third peak is completely sulphated $\left[{ }^{3} \mathrm{H}\right] \mathrm{DSO}_{4}$ in the urine and elutes at a $\mathrm{NaCl}$ concentration of about $1.3 \mathrm{~mol} / \mathrm{l}$. Any material eluting between $0.15 \mathrm{~mol} / 1$ and $1.3 \mathrm{~mol} / \mathrm{l}$ corresponds to partially desulphated $\left[{ }^{3} \mathrm{H}\right] \mathrm{DSO}_{4}$ in the urine.
The percentage of total desulphation of $\left[{ }^{3} \mathrm{H}\right] \mathrm{DSO}_{4}$ (as calculated from the area under the curve), and thus sulphatase activity in urine from control and diabetic rats 1,2, 3 and 4 weeks after the onset of diabetes was found to be $65.6 \pm 0.8 \%$ desulphated $(n=4)$ in urine collected from control rats, $63.4 \pm 1.4 \%$ desulphated $(n=4)$ in urine collected from 1 week diabetic rats, $57.4 \pm 1.4 \%$ desulphated $(n=4, p<0.005$ vs control) in urine collected from 2 week diabetic rats, $56.8 \pm 1.3 \%$ desulphated $(n=4, p<0.005$ vs control) in urine collected from 3 week diabetic rats and $52.9 \pm 2.2 \%$ desulphated $(n=4, p<0.005$ vs control) in urine collected from 4 week diabetic rats. Note that no desulphation was detected in plasma due to extrarenal sources which could have contributed to the desulphation observed in the urine during the $3 \mathrm{~h}$ period of urine collection.

The degree of desulphation of $\left[{ }^{3} \mathrm{H}\right] \mathrm{DSO}_{4}$ in the urine collected from 12 week control and STZ-diabetic rats with and without aminoguanidine or ramipril treatment is shown in Table 2. Diabetes was associated with a considerable decrease in the amount of desulphated $\left[{ }^{3} \mathrm{H}\right] \mathrm{DSO}_{4}$ in the urine that was not affected by drug treatment. The amount of totally desulphated $\left[{ }^{3} \mathrm{H}\right] \mathrm{DSO}_{4}$ was similar to that observed in the 4 weeks STZ-diabetic rats. There was no significant difference in the amount of partially desulphated $\left[{ }^{3} \mathrm{H}\right] \mathrm{DSO}_{4}$ in the urine between all the study groups. However, the increase in totally sulphated $\left[{ }^{3} \mathrm{H}\right] \mathrm{DSO}_{4}$ in the urine collected from diabetic rats was normalised by treatment with aminoguanidine or ramipril. Treatment with aminoguanidine or ramipril did not affect the amount of $\left[{ }^{3} \mathrm{H}\right] \mathrm{DSO}_{4}$ in the urine from control rats.

\section{Discussion}

Previous studies have demonstrated that $\left[{ }^{3} \mathrm{H}\right] \mathrm{DSO}_{4}$ undergoes desulphation during transglomerular transport $[14,15]$. This study showed that in the percentage of totally desulphated $\left[{ }^{3} \mathrm{H}\right] \mathrm{DSO}_{4}$ in urine collected from STZ-diabetic rats decreases as early as two weeks after the onset of diabetes when compared with control rats. These results are in accordance with previous findings of a significant decrease in sulphatase activity in glomerular extracts obtained from 4 week STZ-diabetic rats [15]. This desulphation process occurs within the lysosomes since sulphatase, which is the enzyme responsible for the desulphation, is an acid hydrolase that is specific for lysosomes. Although the changes in desulphation could correspond to a decrease in lysosomal sulphatase activity, they could also reflect changes in the kinetics of the intracellular trafficking of the $\left[{ }^{3} \mathrm{H}\right] \mathrm{DSO}_{4}$ molecule to and from the lysosome.

The reduction in sulphatase activity is likely to reflect alterations synonymous with decreased activities 
of other enzymes associated with lysosomal degradation in diabetes $[6,10-13]$. For example, decreased cathepsin and metalloprotease activities in glomeruli have been shown to decrease after only 4 days of diabetes and to continue to decrease 5 weeks after the onset of diabetes in insulin untreated rats [10]. Transforming growth factor beta, which is upregulated in diabetic nephropathy, has been shown to decrease lysosomal cathepsin activity and consequently protein degradation under hyperglycaemic conditions [32]. The decreased lysosomal enzyme activity observed in the STZ-diabetic rat is consistent with the decrease in albumin fragmentation associated with the "degradation pathway" observed as early as 4 weeks after the onset of diabetes [5]. Thus, the decrease in lysosomal activity in diabetes is probably one of the initial events in the evolution of the disease together with the increased permeability of albumin [33].

This study shows that both aminoguanidine and ramipril prevent the diabetes-induced changes in lysosomal processing as measured by the desulphation of $\left[{ }^{3} \mathrm{H}\right] \mathrm{DSO}_{4}$, despite their different mechanisms of action. Both drugs exerted their effects independently of glycaemic control and neither drug affected glucose or GHb concentrations (Table 1). Aminoguanidine did not affect systolic BP and AER while ramipril prevented increases in both systolic BP and AER (Table 1). Further, urine volume did not decrease in diabetic rats treated with either drug when compared with control rats.

The different effects of aminoguanidine on sulphatase activity as compared with albuminuria are probably related to the different time ramipril and aminoguanidine take to respond and prevent albuminuria. A number of studies have shown that aminoguanidine is effective over the long term but that its efficacy could vary over time. We have previously shown that aminoguanidine prevents albuminuria in STZdiabetic rats at 32 weeks but not at 8 and 16 weeks [24] whereas in another study [6] we showed that aminoguanidine was effective at 8 weeks. Studies with ramipiril have shown that it is consistently effective in preventing albuminuria $[6,25]$. The apparent discrepancy between changes in sulphatase activity and albuminuria (reflecting proteolytic lysosomal processing) is due to the measurement of the intracellular processing of two totally different substrates by different lysosomal enzymes in different renal cells $[6,14]$. Rampiril and aminoguanidine could well have different time-dependent effects at any of the distinct processing points within the cell.

The way in which aminoguanidine and ramipril inhibit the diabetes-induced changes in lysosomal processing suggests that they act on a shared intrarenal pathway when compared with their modes of action at a systemic level. Therefore aminoguanidine and ramipril could either affect the activity of the lysosomal enzymes or the intracellular trafficking of mole- cules to and from lysosomes. Long-term ACE inhibition in a model of chronic renal failure has been shown to restore normal lysosomal cathepsin activity in the heart [34]. However, we have shown that ramipril does not restore cathepsin activity in lysosomes isolated from STZ-diabetic rats 24 weeks after the onset of diabetes [6]. Both of these studies, however, were done in vitro which could affect the measurement of enzyme activity.

We have also recently shown that both aminoguanidine and ramipril inhibit the diabetes-induced activation of protein kinase $\mathrm{C}$ (PKC) in glomeruli. In addition, advanced glycation end product-receptor interactions have been shown to include PKC activation in cultured cells [35] while angiotensin II binding to $\mathrm{AT}_{1}$ receptors in proximal tubular cells has been shown to lead to G-protein coupled activation of phospholipase $\mathrm{C}$ and $\mathrm{D}$ which in turn increases diacylglycerol (DAG) production and PKC activity [36]. The shared intrarenal pathway is likely to involve PKC through its direct actions on the intracellular trafficking of molecules to and from the lysosomes. For example, the effect of PKC on vesicular trafficking has been shown to be a regulatory mechanism that controls endo- and exocytosis of proteins [37-40] including albumin [41]. Farshori and Holzbaur have shown an increased frequency of vesicular transport along microtubules following activation of $\mathrm{PKC}$ and subsequent phosphorylation of dynactin in neurones [42]. In cultured mesangial cells, a glucoseactivated PKC-dependent disruption of the cytoskeleton has been observed [43].

We observed in this study that the diabetes-induced changes in renal lysosomal processing could be one of the initial events in the development of diabetic nephropathy. Aminoguanidine and ramipril, which are known for their different mechanism of action, seem to have similar effects in preventing diabetes-induced changes in lysosomal processing either by a direct effect on enzyme activity within the lysosome or by an effect on the trafficking of molecules to and from the lysosome which could be controlled by PKC.

Acknowledgements. We gratefully thank Ms Brenda Baldacchino for her technical assistance and Mr Ian Goodall for the $\mathrm{GHb}$ analysis. This study was supported by a grant from the Juvenile Diabetes Foundation International and the Diabetes Australia Research Trust.

\section{References}

1. Osicka TM, Comper WD (1997) Protein degradation during renal passage in normal kidneys is inhibited in experimental albuminuria. Clin Sci (Colch) 93: 65-72

2. Osicka TM, Panagiotopoulos S, Jerums G, Comper WD (1997) Fractional clearance of albumin is influenced by albumin degradation. Clin Sci (Colch) 93: 557-564 
3. Osicka TM, Pratt LM, Comper WD (1996) Glomerular capillary wall permeability to albumin and horseradish peroxidase. Nephrology 2: 199-212

4. Burne MJ, Osicka TM, Comper WD (1999) Fractional clearance of high molecular weight proteins in conscious rats using a continuous infusion method. Kidney Int 55: 261-270

5. Burne MJ, Panagiotopoulos S, Jerums G, Comper WD (1998) Alterations in renal degradation of albumin in early experimental diabetes: a new factor in the mechanism of albuminuria. Clin Sci (Colch) 95: 67-72

6. Osicka TM, Yu Y, Panagiotopoulos S et al. (2000) Prevention of albuminuria by aminoguanidine or ramipril in STZ-diabetic rats is associated with the normalisation of glomerular protein kinase C. Diabetes 19: 87-93

7. Osicka TM, Houlihan CA, Chan JG, Jerums G, Comper WD Albuminuria in patients with Type 1 diabetes is directly linked to changes in the lysosomal-mediated degradation of albumin during renal passage. Diabetes 49: 1579-1584

8. Maunsbach AB (1969) Lysosomes in Biology and Pathology. Dingle, JT, Fell HB (eds) Vol 1 pp 115-154

9. Baricos WH, Zhou Y, Fuerst RS, Barrett AJ, Shah SV (1987) The role of aspartic and cysteine proteinases in albumin degradation by rat kidney cortical lysosomes. Arch Biochem Biophys 256: 687-691

10. Teschner M, Schaefer RM, Svarnas A, Heidland U, Heidland A (1989) Decreased proteinase activity in isolated glomeruli of streptozotocin diabetic rats. Am J Nephrol 9: 464-469

11. Schaefer L, Schaefer RM, Ling H, Teschner M, Heidland A (1994) Renal proteinases and kidney hypertrophy in experimental diabetes. Diabetologia 37: 567-571

12. Olbricht CJ, Geissinger B (1992) Renal hypertrophy in streptozotocin diabetic rats: Role of proteolytic lysosomal enzymes. Kidney Int 41: 966-972

13. Shechter P, Boner G, Rabkin R (1994) Tubular cell protein degradation in early diabetic renal hypertrophy. J Am Soc Nephrol 4: 1582-1587

14. Vyas SV, Burne MJ, Pratt LM, Comper WD (1996) Glomerular processing of dextran sulphate. Arch Biochem Biophys 332: 205-212

15. Burne MJ, Adal Y, Cohen N, Panagiotopoulos S, Jerums G, Comper WD (1998) Anomalous decrease in dextran sulphate fractional clearance in the diabetic rat kidney. Am J Physiol 43: F700-F708

16. Velosa JA, Shah SV, Ou SL, Abboud HE, Dousa TP (1981) Activities of lysosomal enzymes in isolated glomeruli: alterations in experimental nephrosis. Lab Invest 45: 522-526

17. Lovett DH, Ryan JL, Kashgarian M, Sterzel RB (1982) Lysosomal enzymes in glomerular cells of the rat. Am J Physiol 107: 161-166

18. Vyas SV, Parker J-A, Comper WD (1995) The uptake of dextran sulphate by glomerular intracellular vesicles during kidney ultrafiltration. Kidney Int 47: 945-950

19. Scandling JD, Myers BD (1992) Glomerular size-selectivity and microalbuminuria in early diabetic glomerular disease. Kidney Int 41: 840-846

20. Deckert T, Kofoed-Enevoldsen A, Vidal P, Nørgaard K, Andreasen HB, Feldt-Rasmussen B (1993) Size- and charge selectivity of glomerular filtration in Type I (insulin-dependent) diabetic patients with and without albuminuria. Diabetologia 36: 244-251

21. Myers BD, Winetz JA, Chui F, Michaels AS (1982) Mechanisms of proteinuria in diabetic nephropathy: A study of glomerular barrier function. Kidney Int 21: 633-641

22. Reckelhoff JF, Tygart VL, Mitias MM, Walcott JL (1993) STZ-induced diabetes results in decreased activity of glo- merular cathepsin and metalloprotease in rats. Diabetes 42: $1425-1432$

23. Soulis-Liparota T, Cooper M, Papazoglou D, Clarke B, Jerums G (1991) Retardation by aminoguanidine of development of albuminuria, mesangial expansion, and tissue fluorescence in streptozotocin-induced diabetic rat. Diabetes 40: $1328-1334$

24. Soulis T, Cooper ME, Vranes D, Bucala V, Jerums G (1996) Effects of aminoguanidine in preventing experimental diabetic nephropathy are related to the duration of treatment. Kidney Int 50: 627-634

25. Allen TJ, Cao Z, Youssef S, Hulthen LU, Cooper ME (1997) Role of angiotensin II and bradykinin in experimental diabetic nephropathy. Functional and structural studies. Diabetes 46: 1612-1618

26. Bunag RD (1973) Validation in awake rats of a tail-cuff method for measuring systolic blood pressure. J Appl Physiol 34: 279-282

27. Cefalu WT, Wang ZQ, Bell-Fallow A, Kiger FD, Izlar C (1994) Glycohemoglobin measured by automated affinity HPLC correlates with both short-term and long-term antecedent glycemia. Clin Chem 40: 1317-1321

28. O'Brien RC, Allen TJ, Cooper ME, Bach LA, Jerums G (1988) Glomerular filtration rate in early experimental diabetes. J Diabetes Complications 2: 8-11

29. Soulis-Liparota T, Cooper ME, Dunlop M, Jerums, G (1995) The relative roles of advanced glycation, oxidation and aldose reductase inhibition in the development of experimental diabetic nephropathy in the Sprague-Dawley rat. Diabetologia 38: 387-394

30. Van Damme M-P, Comper WD, Preston BN (1982) Experimental measurements of polymer unidirectional fluxes in polymer and solvent systems with non-zero chemical potential gradients. J Chem Soc Faraday Trans I 178: 3357-3367

31. Trevelyan WE, Harrison JS (1952) Studies on yeast metabolism. I. Fractionation and microdetermination of cell carbohydrates. Biochem J 50: 298-303

32. Schenk O, Ling H, Sebekova K, Vamvakas S, Heidland A (1998) High-glucose media enhance the responsiveness of tubular cells to growth promoters: Effect of lysosomal cathepsins and protein degradation. Miner Electrolyte Metab 24: $254-260$

33. Tucker BJ, Rasch R, Blantz RC (1993) Glomerular filtration and tubular reabsorption of albumin in preproteinuric and proteinuric diabetic rats. J Clin Invest 92: 686-694

34. Suzuki H, Schaefer L, Ling H et al. (1995) Prevention of cardiac hypertrophy in experimental chronic renal failure by long-term ACE inhibitor administration: Potential role of lysosomal proteinases. Am J Nephrol 15: 129-136

35. Li YM, Mitsuhashi T, Wojciechowicz D et al. (1996) Molecular identity and cellular distribution of advanced glycation endproduct receptors: relationship of p60 to OST-48 and p90 to $80 \mathrm{~K}-\mathrm{H}$ membrane proteins. Proc Natl Acad Sci USA 93: 11047-11052

36. Han HJ, Koh HJ, Park SH (1999) A signaling pathway for stimulation for $\mathrm{Na}+$ uptake induced by angiotensin II in primary cultured rabbit renal proximal tubule cells. J Vet Med Sci 61: 135-141

37. Kurtz A, Pfeilsschifter J, Hutter A et al. (1986) Role of protein kinase $\mathrm{C}$ in inhibition of renin released by vasoconstrictors. Am J Physiol 250: C563-C571

38. Schmalzing G, Richter HP, Hansen A, Schwarz W, Just I, Aktories K (1995) Involvement of the GTP binding protein Rho in constitutive endocytosis in Xenopus laevis oocytes. J Cell Biol 130: 1319-1332 
39. Wright EM, Hirsch JR, Loo DD, Zampighi GA (1997). Regulation of $\mathrm{Na}+$ /glucose cotransporters. J Exp Biol 200: 287-293

40. Quick MW, Corey JL, Davidson N, Lester HA (1997) Second messengers, trafficking related proteins, and amino acid residues that contribute to the functional regulation of the rat brain GABA transporter GAT1. J Neurosci 17: 2967-2979

41. Gekle M, Mildenberger S, Freudinger R, Schwerdt G, Silbernagl S (1997) Albumin endocytosis in OK cells: depen- dence on actin and microtubules and regulation by protein kinases. Am J Physiol 272: F668-F677

42. Farshori P, Holzbaur EL (1997) Dynactin phosphorylation is modulated in response to cellular effects. Biochem Biophys Res Commun 232: 810-816

43. Zhou X, Li C, Dlugosz J, Kapor-Drezgic J, Munk S, Whiteside C (1997) Mesangial cell actin disassembly in high glucose mediated by protein kinase $\mathrm{C}$ and the polyol pathway. Kidney Int 51: 1797-1808 